\title{
THE INTER-AMERICAN COURT OF HUMAN RIGHTS ADVISORY OPINION OC-23/17 ON THE RELATIONSHIP BETWEEN HUMAN RIGHTS AND THE ENVIRONMENT
}

\author{
Przemystaw Siwior*
}

\begin{abstract}
On 15 November 2017, the Inter-American Court of Human Rights issued an advisory opinion OC-23/17 on the relationship between human rights and the environment. The opinion responded to a request made by Colombia pursuant to Article 64(1) of the American Convention on Human Rights regarding extraterritorial jurisdiction of state parties to the Convention resulting from mega-infrastructure projects in the Greater Caribbean region.

The purpose of this article is to discuss the general issues dealt with by the Court, concentrating on the significance of this Advisory Opinion for international law. The opinion contains two main interesting aspects. First, in the light of the opinion, states are responsible for the environmental damage they cause, regardless of whether it occurs within their borders or beyond them. Second, the Advisory Opinion recognizes that the right to a healthy environment is an autonomous, fundamental human right that shall be protected.
\end{abstract}

Keywords: advisory opinion, IACtHR, human rights, environment, extraterritorial jurisdiction

Dr. Przemysław Siwior, Institute of Environmental Protection, National Research Institute; correspondence address: ul. Krucza 5/11D, 00-548 Warsaw, Poland; e-mail: przemyslaw.siwior@kobize.pl; https://orcid.org/0000-0002-1929-5094. 


\section{INTRODUCTION}

On 15 November 2017, the Inter-American Court of Human Rights (Court) rendered an advisory opinion OC-23/17 on the relationship between human rights and the environment (Advisory Opinion). The opinion responded to a request made by Colombia on 14 March 2016 pursuant to Article 64(1) of the American Convention on Human Rights (ACHR) ${ }^{1}$ resulting from extraterritorial jurisdiction of state parties to the ACHR arising from the construction and operation of mega-infrastructure projects in the Greater Caribbean region.

The Advisory Opinion concentrates on obligations of states under international environmental law and human rights law in the transboundary context. It concerns mega-infrastructure projects such as offshore platforms, cross-border pipelines and dams.

The Court's landmark Advisory Opinion includes two main interesting aspects. First, it recognizes that states are responsible for the environmental damage they cause, regardless of whether it occurs within their borders or beyond them. Second, it recognizes that the right to a healthy environment is an autonomous (right in itself), fundamental human right, which must be protected. I will attempt to demonstrate that the Advisory Opinion will have important consequences for international law.

\section{THE INTER-AMERICAN COURT OF HUMAN RIGHTS AND THE BINDING NATURE OF THE ADVISORY OPINION}

The Court began operating in 1979. Twenty states have recognized the jurisdiction of the Court ${ }^{2}$. The Court is composed of seven judges chosen by states parties to the ACHR to six-year, once-renewable terms.

1 Organization of American States, American Convention on Human Rights, San José, Costa, Rica, 22 November 1969, United Nations, Treaty Series, vol 1144, 123, Compilation, vol II.

Argentina, Barbados, Bolivia, Brazil, Chile, Colombia, Costa Rica, Dominican Republic, Ecuador, El Salvador, Guatemala, Haiti, Honduras,Mexico, Nicaragua, Panama, Paraguay, Peru, Suriname, and Uruguay. 
Only states parties and the Commission have the right to bring cases before the court, which has both contentious and advisory jurisdiction ${ }^{3}$.

The Court is authorized to interpret the ACHR and other Inter-American treaties. Organization of American States (OAS) Member States, the IACHR and other organs of the OAS can request an advisory opinion in their respective spheres of competence. The main aim of advisory opinions is to obtain a judicial interpretation of provisions of the ACHR or other treaties. The opinions of the Court are binding. The content of the Court's advisory opinions shall be taken into account, in addition to Court's case judgements. Advisory opinions have a significant preventative role. They act as a guide for states to respect and guarantee human rights in the matters in which the Court has issued an opinion ${ }^{4}$. Advisory jurisdiction varies from contentious jurisdiction to the extent that there is no dispute to be settled.

Since its founding, the Court has rendered 24 advisory opinions. In the past the Court has recognized the existence of a relationship between environmental protection and the enjoyment of other human rights, however only with regard to territorial rights of indigenous and tribal peoples 5 .

3 https://ijrcenter.org/regional/inter-american-system/, accessed February 4, 2021.

4 See Jerzy Jaskiernia, Amerykański system ochrony praw cztowieka (Toruń: Wydawnictwo Adam Marszałek, 2015); Janusz Symonides, "Międzyamerykański Trybunał Praw Człowieka," in Historia. Stosunki międzynarodowe. Amerykanistyka. Księga Jubileuszowa na 65-lecie Profesora Wiestawa Dobrzyckiego, ed. Stanisław Bieleń (Warsaw: ASPRA-JR, 2001), 541; Robert Tabaszewski, "Międzyamerykański Trybunał Praw Człowieka jako panamerykański organ sądowniczy," in Oblicza Ameryki Łacinskiej, ed. Katarzyna Krzywicka and Joanna Kaczyńska (Lublin: Wydawnictwo UMCS, 2010), 89-90.

5 Jose Felix Pinto-Bazurco, "The Inter-American Court of Human Rights Recognizes a Right to a Healthy Environment in Recent Advisory Opinion," 2018, /http://blogs .law.columbia.edu/climatechange/2018/02/23/the-inter-american-court-of-human-rightsrecognizes-a-right-to-a-healthy-environment-in-recent-advisory-opinion/, accessed February 4, 2021. 


\section{TWO MAIN ISSUES ADDRESSED BY THE COURT}

In the Advisory Opinion, the Court addressed two main issues:

1) the application of extraterritorial jurisdiction to environmental obligations and

2) the relationship between human rights and environmental harm.

It is important to point out that the Advisory Opinion was much awaited ${ }^{6}$.

\subsection{The application of extraterritorial jurisdiction to environmental obligations}

Colombia sought clarification on the interpretation of the term "jurisdiction" in Article 1(1) 7 of the ACHR, in the context of compliance with environmental obligations, especially in relation to conduct outside the national territory of a state, or with effects that go beyond the national territory of a state.

The Court pointed out that the states parties to the ACHR have the obligation to respect and guarantee the rights outlined in this convention to all persons subject to their jurisdiction (para. 77). The Court explained that, the object and aim of the ACHR are not limited to the concept of the national territory, but encompass circumstances in which the extraterritorial conduct of a state constitutes an exercise of its jurisdiction (para. 78). A person is under the jurisdiction of the state of origin if there is a causal nexus between the action that occurred within its territory and the negative impact on the human rights of persons outside its territory (para. 104).

The Court pointed out that international human rights law (ECHR) has recognized various situations in which the extraterritorial conduct of a state entails the exercise of its jurisdiction (para. 79). However, the Court determined that the exercise of jurisdiction under Article 1(1) of the ACHR outside of a state's territory is an exceptional case that shall be examined

6 https://www.corteidh.or.cr/sitios/libros/todos/docs/infografia-eng.pdf, accessed February 4, 2021.

Pursuant to Article 1(1) of the ACHR: "The States Parties to this Convention undertake to respect the rights and freedoms recognized herein and to ensure to all persons subject to their jurisdiction the free and full exercise of those rights and freedoms, without any discrimination $[\ldots]$ ". 
by following the factual and juridical circumstances of each concrete case and applied in a restrictive manner (para. 81). The Court held that effective control over the source of environmental harm (activities that caused the damage) alone may be sufficient to give rise to state responsibility if there is a relation of causality (if there is a causal nexus) between the act that originated in its territory and the violation of the human rights of persons outside its territory (paras. 101-102).

The Advisory Opinion could result in human rights claims in circumstances wider than those that have been held admissible under the ACHR so far. The Court's interpretation comes from the due diligence rule and is supported by the Trail Smelter Case ${ }^{8}$.

\subsection{The relationship between human rights and environmental harm}

The Court had already linked the right to life with the environment in cases concerning indigenous communities and their living conditions, however the Court had so far kept these two topics separate?

The Court identified a close link between a number of substantive human rights ${ }^{10}$, procedural rights and the right to a healthy environment. With reference to the negative obligation to respect human rights, the Court pointed out that states should refrain from:

1) any activity that denies or restricts access to a decent life; and

2) illegal pollution of the environment.

8 Decision of April 16 1938, and 11 March 1941, Case Trail Smelter Case (United States v. Canada), 1965; see Ricardo Abello-Galvis and Walter Arevalo-Ramirez, "Inter-American Court of Human Rights Advisory Opinion OC-23/17: Jurisdictional, procedural and substantive implications of human rights duties in the context of environmental protection," Review of European, Comparative \& International Environmental Law 28, Issue 2 (2019): 217-218.

9 IACrtHR Judgment of 17 June 2005, Case Yakye Axa Indigenous Community v. Paraguay, Inter-American Court of Human Rights Series C No 125, para. 137; IACrtHR Judgment of 29 March 2006, Case Sawhoyamaxa Indigenous Community v. Paraguay, Inter-American Court of Human Rights Series C No 146, para. 118; see Abello-Galvis and Arevalo-Ramirez, "Inter-American Court," 217.

10 Right to life, right to housing, right not to be forcefully displaced, right to personal integrity, right to participate in cultural life, right to health, right to water, right to food, property rights. 
Positive obligations apply when:

1) the authorities of the state knew or should have known that there is a real and imminent danger for the life of a specific individual or group of individuals and failed to take the necessary measures within their area of responsibility, which could reasonably be expected to prevent or to avoid that danger; and

2) there is a causal nexus between the violation and the significant damage to the environment (para. 120).

The Court found that states have to respect the following specific obligations:

1) the obligation of prevention (para. 127-174) - states have to prevent significant environmental damages within and outside their territory in circumstances that could be considered under the jurisdiction of that state. Obligation of prevention encompasses:

(i) the duty to regulate (derived from Article 2 of the ACHR) activities, which might induce significant damage to the environment;

(ii) the duty to supervise and monitor - states have to implement adequate and independent monitoring and accountability mechanisms that include preventive measures, as well as measures needed to investigate, punish and repair potential abuses;

(iii) the duty to require and approve environmental impact assessment in case of risk of significant damage to the environment. In accordance with the due diligence rule, an environmental impact assessment must be done before the proposed activity by independent bodies. An environmental impact assessment has to address cumulative impacts, allow public participation and respect the traditions and culture of indigenous peoples; ${ }^{11}$

(iv) the duty to establish a contingency plan (an obligation which is also included in some environmental treaties $\left.{ }^{12}\right)$;

11 Para. 163.

12 See, e.g., United Nations, Convention on the Law of the Non-navigational Uses of International Watercourses, New York 21 May 1997 as amended, UN Doc. A/51/869, reprinted in 36 I.L.M. 700, Article 28. 
(v) the obligation to mitigate - states have to mitigate significant environmental damage, even in case when it has appeared despite preventive measures.

2) obligation to act in line with the precautionary principle in case of possible serious and irreversible damage to the environment, even if there is a lack of scientific certainty. It should be noted that the Court went beyond the established case law in cases such as Case Pulp Mills on the River Uruguay ${ }^{13}$ and concluded that, even in case of absence of scientific evidence, states have to take any measure necessary to prevent infringements of the right to life (paras. 175-180).

3) obligation to cooperate (paras. 181-210) - states when they become aware that activity planned under their jurisdiction may cause a risk of significant transboundary damage and in cases of environmental emergencies should notify other states and consult, negotiate with the states potentially influenced by significant transboundary harm.

4) Procedural obligations (paras. 211-241) - states must ensure:

(i) the right of access to information established by Principle 10 of the Rio Declaration on Environment and Development ${ }^{14}$ and Article 13 of the ACHR in relation to possible damage to the environment without need to prove a personal or direct interest (paras. 213-225);

(ii) the right to public participation of the persons subject to their jurisdiction as granted under the terms of Article 23(1)(a) of the ACHR, in any decision-making process and in the issuing of policies, which could influence the environment (paras. 226-232);

(iii) proper and effective access to justice through national courts (paras. 233-240) ${ }^{15}$.

The obligations described above have been developed in relation to the general obligations to respect and ensure the rights to life and personal

13 ICJ Judgment of 20 April 2010, Case Pulp Mills on the River Uruguay (Argentina v. Uruguay).

14 United Nations, Rio Declaration on Environment and Development, Rio de Janeiro, 12 August 1992, UN Doc A/CONF.151/26 (vol I).

15 Abello-Galvis and Arevalo-Ramirez, "Inter-American Court," 221. 
integrity. However, the Court pointed out that this did not mean that the same duties did not apply to other human rights (para. 243).

The Court indicated that environmental obligations are usually based on the duty of due diligence rule - understood as a duty of behavior rather than of result (para. 124).

\section{AUTONOMOUS RIGHT TO A HEALTHY ENVIRONMENT}

Another substantial and commendable aspect of the Advisory Opinion is the Court's affirmation of an autonomous right to a healthy environment (para. 62) under Article 26 of the ACHR. The Court declared an autonomous right to a healthy environment (right in itself). According to the Court, the right to a healthy environment is encompassed by Article 26 of the ACHR which provides for the progressive realization of economic, social, and cultural rights (progressive development) and finds reflection in states' constitutions as well as international instruments (para. 57). In the view of the Court, the right to a healthy environment is an autonomous right [derecho autónomo] which protects elements of the environment, such as forests, rivers, seas, and other such elements, even in the absence of certainty or evidence of risk to individual persons and is a fundamental right for the existence of humankind. The reason is the environment's importance for the other living organisms (para. 62). The Court stressed the undisputed relationship between the protection of the environment and the protection of "other human rights" owing to the fact that the infringement of this autonomous right to a healthy environment could influence other human rights, in particular the right to life and personal integrity and many other rights including health, water, housing, and procedural rights (e.g. right to information, association, participation, and expression).

The Court's declaration that the right to a healthy environment is an autonomous right signifies that there can now be claims solely for environmental harm, meaning that harm to human rights is not needed.

According to the Court, the right to a healthy environment is a right with individual and collective associations (para. 47). As an individual right, it is inseparably interlinked with other fundamental rights (e.g. right 
to life, personal integrity, right to health). As a collective right, it is a subject of interest of the humankind and of the future generations ${ }^{16} .{ }^{17}$

It should be pointed out that this finding of a legal ground under Article 26 for an autonomous right to a healthy environment generated much discussion and debate among the Court's members, issuing two concurring opinions ${ }^{18}$.

\section{CONCLUSIONS}

The Court delivered a groundbreaking interpretation of states' duties in relation to the exercise of jurisdiction in cases of environmental damage that goes beyond traditional international legal doctrines on state jurisdiction ${ }^{19}$. For the first time in history, an international human rights court examined thoroughly environmental law separately from single cases of environmental harm (e.g. Case López Ostra v. Spain ${ }^{20}$ in the ECHR ${ }^{21}$.

It seems that, the Advisory Opinion's reasoning could be used in air pollution, chemicals and climate change cases. Given that international

16 Domenico Giannino, "The Ground-Breaking Advisory Opinion OC-23/17of the Inter-American Court of Human Rights: Healthy Environment and Human Rights, Int'l J.Const. L. Blog," 2018, http://www.iconnectblog.com/2018/12/the-groundbreaking-advisory-opinion-oc-23-17-of-the-inter-american-court-of-human-rights -healthy-environment-and-human-rights/, accessed February 4, 2021.

17 See Roman Kuźniar, Prawa Cztowieka. Prawo, Instytucje, Stosunki Międzynarodowe (Warsaw: Wydawnictwo naukowe Scholar, 2004), 209-221; Krzysztof Orzeszyna, Michał Skwarzyński, and Robert Tabaszewski, Prawo międzynarodowe praw cztowieka (Warsaw: C.H. Beck, 2020), 168.

18 See Angeliki Papantoniou, "Advisory Opinion on the Environment and Human Rights," American Journal of International Law 112, Issue 3 (2018): 460-466.

19 Abello-Galvis and Arevalo-Ramirez, "Inter-American Court," 217.

20 ECtHR Judgement of 09 December 1994, Case López Ostra v. Spain, application no. $16798 / 90$, hudoc.int.

${ }_{21}$ Council of Europe, European Convention on Human Rights and Fundamental Freedoms, Rome, 4 November 1950 as amended by Protocols Nos. 11 and 14 supplemented by Protocols Nos. 1, 4, 6, 7, 12, 13 and 16, ETS No. 5: ETS No. 009, 4: ETS No. 046, 6: ETS No. 114, 7: ETS No. 117, 12: ETS No. 177. 
rulings are frequently followed by other international courts and tribunals, it should be expected that the Advisory Opinion may influence jurisprudence worldwide. It may constitute the practice of other human rights tribunals (e.g. the ECtHR) and national courts. For decades, the Court's rulings have advanced progressive jurisprudence at international bodies across the world. The Advisory Opinion is likely to have significant consequences for states, businesses and civil society. It confirms the increasing need to take into account fast developments in human rights and environmental law. The key importance of the Advisory Opinion is that it theoretically enables human rights claims in cases that have been held inadmissable under the ACHR so far $^{22}$.

The Advisory Opinion indicates the growing significance of human rights and environmental matters in international law and the possibilities they offer for international dispute settlement. It gives rise to cross-border human rights claims resulting from transboundary environmental harm. It also does not limit such claims to damages induced by states' agents but says that in such cases, state's jurisdiction encompasses activities over which a state has 'effective control' 23 .

The Court's affirmation of an autonomous right to a healthy environment means that in cases before the Court, applicants may directly claim that their right to a healthy environment is infringed, instead of claiming that their right to life, personal integrity or another related right is violated by environmental harm.

Now it is time for applicants to examine the potential and limits of the progressive jurisprudence. Many key aspects of the Advisory Opinion, including the causal nexus, requires a level of due diligence and the scope of extraterritorial obligations, will have to be explained in the near future by the Court.

22 Monica Feria-Tinta and Simon Milnes, "The Rise of Environmental Law in International Dispute Resolution: The Inter-American Court of Human Rights Issues a Landmark Advisory Opinion on the Environment and Human Rights," Yearbook of International Environmental Law 27, no. 1 (2016): 75.

23 Ibid. 


\section{REFERENCES}

Abello-Galvis, Ricardo, and Walter Arevalo-Ramirez. "Inter-American Court of Human Rights Advisory Opinion OC-23/17: Jurisdictional, procedural and substantive implications of human rights duties in the context of environmental protection." Review of European, Comparative \& International Environmental Law 28, Issue 2 (2019): 217-222.

Berkes, Antal. "A New Extraterritorial Jurisdictional Link Recognised by the IACtHR." 2018. https://www.ejiltalk.org/a-new-extraterritorial-jurisdictional-link-recognised-by-the-iacthr/. Accessed February 4, 2021.

Feria-Tinta, Monica, and Simon Milnes. "The Rise of Environmental Law in International Dispute Resolution: The Inter-American Court of Human Rights Issues a Landmark Advisory Opinion on the Environment and Human Rights." Yearbook of International Environmental Law 27, no. 1 (2016): 64-81.

Giannino, Domenico. "The Ground-Breaking Advisory Opinion OC-23/17of the Inter-American Court of Human Rights: Healthy Environment and Human Rights, Int'l J.Const. L. Blog.” 2018. http://www.iconnectblog. com/2018/12/the-ground-breaking-advisory-opinion-oc-23-17-of-the-interamerican-court-of-human-rights-healthy-environment-and-human-rights/. Accessed February 4, 2021.

Jaskiernia, Jerzy. Amerykański system ochrony praw cztowieka. Toruń: Wydawnictwo Adam Marszałek, 2015.

Kuźniar, Roman. Prawa Cztowieka. Prawo, Instytucje, Stosunki Międzynarodowe. Warsaw: Wydawnictwo naukowe Scholar, 2004.

Orzeszyna, Krzysztof, Michał Skwarzyński, and Robert Tabaszewski. Prawo międzynarodowe praw cztowieka. Warsaw: C.H. Beck, 2020.

Papantoniou, Angeliki. "Advisory Opinion on the Environment and $\mathrm{Hu}-$ man Rights." American Journal of International Law 112, Issue 3 (2018): 460-466.

Pinto-Bazurco, Jose Felix. "The Inter-American Court of Human Rights Recognizes a Right to a Healthy Environment in Recent Advisory Opinion." 2018. http://blogs.law.columbia.edu/climatechange/2018/02/23/the-inter-americancourt-of-human-rights-recognizes-a-right-to-a-healthy-environment-in-recentadvisory-opinion/. Accessed February 4, 2021.

Symonides, Janusz. "Międzyamerykański Trybunał Praw Człowieka.” In Historia. Stosunki międzynarodowe. Amerykanistyka. Ksiega Jubileuszowa na 65-lecie Profesora Wiestawa Dobrzyckiego, edited by Stanisław Bieleń, 537-552. Warsaw: ASPRA-JR, 2001. 
Tabaszewski, Robert. "Międzyamerykański Trybunał Praw Człowieka jako panamerykański organ sądowniczy.” In Oblicza Ameryki Eacińskiej, edited by Katarzyna Krzywicka, and Joanna Kaczyńska, 83-94. Lublin: Wydawnictwo UMCS, 2010. 